\title{
Accumulation and mobilization of lipids in relation to reproduction of yellowfin tuna (Thunnus albacares) in the Western Indian Ocean
}

\author{
Iker Zudaire $^{\mathrm{a}, *}$, Hilario Murua ${ }^{\mathrm{a}}$, Maitane Grande $^{\mathrm{a}}$, Fabrice Pernet $^{\mathrm{c}}$, Nathalie Bodin ${ }^{\mathrm{b}}$
}

\author{
${ }^{a}$ AZTI-Tecnalia, Marine Research Division, Herrera Kaia-Portu aldea z/g, Pasaia, Gipuzkoa 20110, Spain \\ ${ }^{\mathrm{b}}$ IRD - UMR 212 EME, Avenue Jean Monnet, BP 171, 34200 Sète, France \\ ${ }^{c}$ Ifremer - Centre Bretagne, ZI de la Pointe du Diable, CS 10070, 29280 Brest, Plouzané, France \\ *: Corresponding author : Iker Zudaire, tel.: +34 660061499 ; fax: +34 946572555 ; \\ email address : iker.zuda@gmail.com
}

\begin{abstract}
:
Total lipid content and lipid class composition were analyzed in gonads, liver and white muscle of yellowfin tuna (Thunnus albacares) throughout ovary development to understand its reproductive allocation strategy and to assess the relation between female condition and reproduction. A total of 112 females were collected onboard purse-seiner in the Western Indian Ocean from January to March 2009, from June to July 2009, and from April to May 2010. Gonads were characterized by highly variable total lipid contents ranging from 5 to $27 \mu \mathrm{g} \mathrm{mg}^{-1}$ of wet weight (ww) with a predominance of neutral lipids, mainly triacylglycerols (TAG) and sterol- and wax-esters. The different lipid classes in gonads described an accumulative pattern through the maturity process from immature to hydration phase. Total lipid content in liver varied from 10 to $21 \mathrm{mg} \mathrm{mg}^{-1} \mathrm{ww}$, and serves as fuel for yellowfin tuna reproduction. TAG and phospholipid deposits became depleted as the ovary developed, suggesting a transfer of lipids directly from liver to the oocytes during vitellogenesis. In contrast, muscle total lipid content was low and constant throughout ovarian development $\left(2.5-6 \mu \mathrm{g} \mathrm{mg}^{-1} \mathrm{ww}\right.$ ). Hence, yellowfin tuna can be defined as an income-capital breeder species for which the cost of reproduction depends mainly on concurrent energy income from feeding and only little on stored lipids. Besides, no significant relationship between gonad lipid composition and fecundity was found in females able to spawn. Finally, the influence of yellowfin tuna aggregation behaviour on reproductive female condition has been investigated: gonad total lipid contents were higher in females caught in free-swimming schools than in females caught under fish aggregating devices (FADs). However, these results did not clarify whether the influence of FADs on associated yellowfin tuna affects their reproductive capacity.
\end{abstract}

Keywords : Tropical tuna ; Lipid class composition ; Reproductive allocation strategy ; Income-capital breeder ; Fecundity ; FADs 


\section{Introduction}

The reproductive process implies energetic and physiological costs that could endanger current reproduction as well as the survival of individuals and/or future reproduction (Stearns, 1992). A decrease in acquired energy prior to and/or during the spawning period could negatively impact on different reproductive traits such as maturation, fecundity, and egg quality and size (Henderson et al., 1996, Izquierdo et al., 2001, Kjesbu et al., 1998, Margulies et al., 2007, Sargent et al., 2002 and Wiegand et al., 2007). Lipids are the major metabolic energy resource involved in the reproductive process in fishes (Johnson, 2009), and can be (i) mobilized from storage tissues to the developing oocytes, (ii) acquired directly from food or (iii) de novo synthesized in the ovarian follicles (Wiegand, 1996). A major proportion of lipids are catabolized to provide metabolic energy required for reproductive processes, while some are transferred via serum as vitellogenin proteins (rich in polar lipids; referred to as $\mathrm{Vtg}$ ) and very low-density lipoproteins (rich in neutral lipids; referred to as VLDL), and deposited as yolk reserves in the oocytes (Sargent, 1995).

Lipids dynamic through the reproductive cycle is related to the functions of each lipid class during reproduction (Norton and MacFarlane, 1999), and a decrease in their quantity could limit fish productivity (Henderson et al., 1996, Marshall et al., 1999 and Wiegand et al., 2007) and affect the viability of progeny (Rainuzzo et al., 1997). The different reproductive strategies adopted by the species also influence lipid acquisition in females (AlonsoFernández and Saborido-Rey, 2012 and Aristizabal, 2007). Fishes with synchronous oocyte development are likely to acquire the energy they require prior to the reproductive period (i.e., capital breeders), whereas fishes with asynchronous oocyte development are more dependent on current energy income from feeding (i.e., income breeders) (McBride et al., 2013). The boundary between both strategies is not always so clear and a range of strategies could be developed by species (Houston et al., 2006). The 
monitoring of different condition indices throughout the reproductive cycle has suggested that yellowfin

61 tuna could act as an income-capital breeder (Zudaire et al., 2013b), which means that the cost of

62 reproduction is mainly offset by current energy income due to feeding activity during the spawning

63 period, although some of the invested resources could come from stored energy acquired before the

64 reproductive period. Other factors like the environmental conditions, food availability and fish migration

65 can also affect lipid content and, consequently, the reproductive potential of individual fish (Henderson et

66 al., 1996, 1998; Izquierdo et al., 2001; Wiegand et al., 2007). The intensive use of fish aggregating

67 devices (FADs) by tuna purse-seine fisheries has been hypothesized (Hallier and Gaertner, 2008; Marsac

68 et al., 2000) that may have negative impacts on tuna movement and migration, leading them to low-

69 quality habitats, with potential detrimental effects on individual and population productivity. Studies on

70 tagged tunas (Dagorn et al., 2007; Schaefer and Fuller, 2010) have estimated a residence time of 3-8 days

71 for tuna individuals associated to FADs. Yellowfin tuna has a high metabolic rate (Bertrand et al., 2002)

72 and females are able to tune rapidly their reproductive effort to variation in the food availability

73 (Margulies et al., 2007). Several studies have dealt with the assessment of these potential impacts that

74 FADs could exert on different aspects of tuna biology (Dagorn et al., 2012; Jaquement et al., 2011), but

75 none of them looked at the potential impact of FADs on lipid dynamics during reproduction.

77 Yellowfin tuna is a large epipelagic species widely distributed in the tropical and subtropical waters of the major oceans (Collette and Nauen, 1983). It is a highly migratory species, growing rapidly and with early maturation (Schaefer, 1998, 2001; Juan-Jordá et al., 2013). Yellowfin tuna exhibits indeterminate

80 fecundity with asynchronous oocyte development (Zudaire et al., 2013a). Spawning occurs in multiple

81 batches (Schaefer, 1996, 1998) all year round in tropical regions (Schaefer, 2001) and the spawning

82 frequency for Pacific specimens was estimated around 1.5 days (McPherson, 1991; Schaefer, 1998). In

83 the Western Indian Ocean, some studies identified two reproductive periods (Zudaire et al., 2013b;

84 Stequert el al. 2001); the main one from November to March and a second peak in June, while others

85 authors identified a single spawning peak during the main period (Stéquert and Marsac, 1989; Zhu et al.,

86 2008). The mean batch fecundity in the Indian Ocean has been estimated to be 3.1 million oocytes

87 (Zudaire et al., 2013b), and Schaefer (1996) revealed that a female yellowfin tuna in the Pacific Ocean

88 would spawn the equivalent of about 3.5 times its body weight per year. The last assessment of the 
89 Yellowfin carried out in the Indian Ocean estimated that the stock is not overfished and that overfishing is

90 not occurring (IOTC, 2012).

91

92 Most of the previous studies on lipid dynamics during sexual maturation were conducted in temperate

93 tunas (Mourente et al., 2002; Zaboukas et al., 2006), and only few studies were conducted on yellowfin

94 tuna which mainly were focused on human nutritional requirements (Medina et al., 1995; Saito et al.,

95 1996). To our knowledge, there is a lack of information regarding the lipid accumulation and mobilization

96 process related with yellowfin tuna reproduction. Describing the role of each lipid class during oocyte

97 development and analysing the relationships between lipids and fecundity could provide a better

98 understanding of the reproductive potential of the yellowfin tuna stocks in the Western Indian Ocean

99 (Marshall et al., 1999). Thus, the main purpose of this study was to describe the energy allocation strategy

100 for reproduction by investigating total lipid content and lipid class composition and the process of their

101 allocation during ovarian development in the muscle, liver and gonads of female yellowfin tuna from the

102 Western Indian Ocean. The relationship between total lipid and lipid class concentrations in these tissues

103 and fecundity was also investigated. Finally, the influence of school types (FADs vs. free-swimming

104 schools) on yellowfin tuna condition was evaluated, and the possible consequences for reproductive

105 potential were discussed.

106

107 2. Material and Methods

108

$109 \quad$ 2.1. Field sampling

110 Sampling was carried out by scientific observers onboard commercial purse-seiner. Two surveys in 2009

111 (from January $21^{\text {st }}$ to March $23^{\text {rd }}$ and from June $5^{\text {th }}$ to July $25^{\text {th }}$ ) and one survey in 2010 (From April $3^{\text {rd }}$ to

112 May $21^{\text {st }}$ ) were conducted in the Western Indian Ocean (Fig. 1). Each fish was measured (fork length, FL)

113 to the nearest centimeter and weighed to the nearest tenth of a kilogram. Liver and gonad weights were

114 recorded to the nearest gram. A 4-5-cm cross section of the gonads was cut in-between the middle/end

115 part of the right or left lobe and preserved in a solution of $4 \%$ buffered formaldehyde for subsequent

116 histological analysis to assess the maturation status and fecundity. For lipid analysis, 10-g samples of

117 gonads, liver and white muscle from the dorsal part of the fish between the head and the first dorsal fin 
118 were collected. Each sample was stored at $-20^{\circ} \mathrm{C}$ onboard, and then transferred at $-80^{\circ} \mathrm{C}$ to a laboratory

119 until further lipid analysis.

120

121 Three condition indices, the gonadosomatic index (GSI), the hepatosomatic index (HSI) and Fulton's

122 condition factor $(\mathrm{K})$, were estimated as follows:

$123 \mathrm{GSI}=\left(W_{g} / W_{f}\right) \times 10^{2}$

$124 \quad \mathrm{HSI}=\left(W_{l} / W\right) \times 10^{2}$

$125 \mathrm{~K}=\left(W / L^{3}\right) \times 10^{2}$

126 where $\mathrm{W}_{\mathrm{g}}$ and $\mathrm{W}_{\mathrm{l}}$ correspond to the gonad and liver weights (in grams) respectively, $\mathrm{W}_{\mathrm{f}}$ is the gonad-free 127 body weight and $\mathrm{W}$ is total weight of the fish (in grams). $\mathrm{L}$ is the fork length (in centimeters).

\subsection{Histological analysis}

130 The histological classification of yellowfin tuna ovaries followed the terminology established in Zudaire

131 et al. (2013a). The ovaries were classified according to the most advanced oocyte stage present in the

132 ovary: immature phase (IP), which includes oocytes in the primary growth stage (PG); developing phase

133 (DP), which includes cortical alveoli (CA), primary vitellogenesis (Vtg1) and secondary vitellogenesis

134 (Vtg2) oocyte stages; spawning-capable phase (SCP), which includes tertiary vitellogenesis (Vtg3),

135 germinal vesicle migration (GVM) and hydration (HYD) stages; and regenerating phase (RP), which is

136 characterised by the presence of late-stage atresia and a thicker ovarian wall than seen in immature fish.

\section{2.3. Fecundity analysis}

139 The batch fecundity (BF), i.e., the total number of oocytes released per batch, and the number of

140 developing oocytes (NDO), i.e., the standing stock of yolked oocytes in the ovary (Murua and Motos,

141 2006), were estimated. The BF was determined using the gravimetric method (Hunter et al., 1989) by

142 counting the oocytes at the most advanced stage of maturation (including GVM and HYD). For BF

143 analyses, three subsamples of $0.1 \pm 0.01 \mathrm{~g}$ from each ovary were collected. BF was calculated as the

144 weighted mean density of the subsamples multiplied by the total weight of the ovary. The NDO was

145 estimated in ovaries at SCP, with Vtg3 as the most advanced oocyte stage. For NDO estimation, the

146 minimum threshold of CA oocyte size was established at $120 \mu \mathrm{m}$ by Zudaire et al. (2013a). The standing

147 stock of yolked oocytes was counted using ImageJ free software (Rasband, W.S., ImageJ, U.S. National 
148 Institutes of Health, Bethesda, Maryland, USA, http://rsb.info.nih.gov/ij/, 1997-2012) based on protocol 149 described in Zudaire et al. (2013a).

150

2.4. Lipid class analysis

152 Each 10-g sample was first subjected to cryogenic grinding by using a mixer mill, MM400 Retsch ${ }^{\circledR}$

153 (Verder, France). This process had to be carried out as rapidly as possible to avoid lipid degradation. A

154 subsample $(0.1 \pm 0.001 \mathrm{~g})$ of the homogenized powder was then weighed under a nitrogen atmosphere.

155 Total lipids were extracted following a Folch method (Folch et al., 1957), spotted onto S-III Chromarods

156 (Iatron Laboratories Inc., Tokyo, Japan), and finally separated into SE-WE, ketones (KET), TAG, free

157 sterols (ST), acetone mobile polar lipids (AMPL) and PL (Parrish, 1999). Chromarods were scanned

158 using an Iatroscan MK-VI (Iatron Laboratories) thin-layer chromatography-flame-ionization detector

159 analyser (TLC-FID). Concentrations of lipid classes are expressed as $\mu \mathrm{g} \mathrm{mg}^{-1}$ on a wet weight (ww)

160 basis. Total lipid content $\left(\mu \mathrm{g} \mathrm{mg}^{-1} \mathrm{ww}\right)$ corresponds to the sum of lipid classes, and enables estimation of 161 the relative contribution (\%) of each lipid class to the total fat.

162

163 2.5. Statistical analysis

164 A two-way split plot ANCOVA was used to estimate differences in lipid class concentrations as a

165 function of maturity stage and tissues (gonads, liver and muscle). Condition indices (GSI, HSI and K) and

166 fork length were used as covariates. The unit of replication was the fish in which maturity stage was

167 determined. The main plots were maturity stages and subplots were tissues. Here we used a mixed linear

168 model, which models not only the means of our data but their variances and covariances. The need for

169 covariance parameters arose because the experimental units (fish) on which the variables were measured

170 were grouped into clusters and repeated measurements (tissue) were taken on the same experimental unit.

171 The repeated option was applied to the term 'Tissue'. Where differences were detected, least-square

172 means multiple comparison tests were used to determine which means were significantly different. A

173 three-way split plot ANOVA was used to estimate differences in lipid class concentrations as a function

174 of school types (FADs vs. free-swimming schools), maturity stage and tissues. The main plots were

175 school types and maturity stages and subplots were tissues. The repeated option was applied to the term

176 'Tissue'. Only females with ovaries at DP and SCP were included in this model to focus on mature

177 females involved in the current reproductive process. Due to the absence of females with hydrated ovaries 
178 (HYD) collected under FADs, this stage was excluded from the model. Finally, the relationships between

179 fecundity and condition indices and lipid classes were investigated using stepwise regression models. For

180 all statistical analyses, residuals were screened for normality using the expected normal probability plot.

181 When necessary, data were log+1 transformed to achieve normality of residuals and homogeneity of

182 variances. Homogeneity of variance-covariance matrices was graphically assessed. Analyses were carried 183 out using SAS 9.1.3 (SAS Institute Inc., Cary, NC, USA).

184

185

\section{Results}

186

187 A total of 112 yellowfin tuna were sampled: 67 females were caught under FADs and 45 females in free-

188 swimming schools. The fishes caught at FADs ranged from 50 to $120 \mathrm{~cm}$ FL and a total weight from 2.4

189 to $33.0 \mathrm{~kg}$ and fishes caught in free-swimming schools ranged from 56 to $153 \mathrm{~cm}$ FL and a total weight

190 from 3.7 to $63.9 \mathrm{~kg}$ (Table 1). Table 2 describes the numbers of sampled females, the fish size range $(\mathrm{cm})$,

191 as well as the mean values ( \pm standard error, SE) of the condition indices (GSI, HSI and K) and the

192 concentrations of total lipids in the three tissues (gonads, liver and muscle) by ovarian development

193 phases. Overall, the highest contents of total lipid in gonads were observed in females at the spawning-

194 capable phase $\left(26.7 \pm 0.2 \mu \mathrm{g} \mathrm{mg}^{-1}\right)$, while the lowest values were found in ovaries of developing-phase

195 females $\left(4.8 \pm 0.1 \mu \mathrm{g} \mathrm{mg}^{-1}\right)$. Liver exhibited the opposite pattern, with the highest total lipid contents in

196 immature phase females $\left(20.8 \pm 0.1 \mu \mathrm{g} \mathrm{mg}^{-1}\right)$ and the lowest in females at the spawning-capable phase

$197\left(10.3 \pm 0.4 \mu \mathrm{g} \mathrm{mg}^{-1}\right)$. Gonads and liver exhibited around threefold and fourfold higher total lipid contents

198 than muscle, in which the highest and lowest total lipids were found in immature phase $\left(5.9 \pm 0.1 \mu \mathrm{g} \mathrm{mg} \mathrm{g}^{-1}\right)$

199 and spawning-capable phase females $\left(2.9 \pm 0.5 \mu \mathrm{g} \mathrm{mg}^{-1}\right)$, respectively.

200

201

\subsection{Lipid class composition along the reproductive cycle}

202 All females presented in the Table 2 were selected for the analysis of the lipid class composition along the

203 reproductive cycle. The outputs of mixed ANCOVA model described weak but significant positive

204 relationships between FL and TAG concentrations $\left(\mathrm{r}^{2}=0.121 ; P<0.05\right)$, as well as between FL and

205 TAG/ST ratio $\left(\mathrm{r}^{2}=0.225 ; P<0.05\right)$ in yellowfin gonads (Fig. 2A and $2 \mathrm{~B}$, respectively). Similarly, a

206 positive relationship between HSI and TAG/ST ratio $\left(\mathrm{r}^{2}=0.109 ; P<0.05\right)$ was observed in liver (Fig. 2D).

207 In contrast, a negative relationship was observed in the muscle between total lipids and FL $\left(\mathrm{r}^{2}=0.196\right.$; 
$P<0.05)$ (Fig. 2C). The interaction of Maturity $\times$ Tissue was significant $(P<0.05)$ for all the different lipid classes, except ketones (Table 3); which indicate that different lipid classes in liver, muscle and

210 gonad varies with maturity stage (further described below).

212 In gonads, TAG concentrations showed a clear accumulative pattern through maturation (Fig. 3A). While

213 PG and CA stages exhibited low values $\left(1.3 \pm 0.2 \mu \mathrm{g} \mathrm{mg}^{-1}\right.$ and $0.6 \pm 0.1 \mu \mathrm{g} \mathrm{mg}^{-1}$, respectively), TAG

214 increased significantly during vitellogenesis to reach the maximum levels in $\operatorname{Vtg} 3\left(7.3 \pm 0.2 \mu \mathrm{g} \mathrm{mg}^{-1}\right)$ and

$215 \operatorname{GVM}\left(7.5 \pm 0.5 \mu \mathrm{g} \mathrm{mg}^{-1}\right)$. Then, TAG decreased drastically, leading to concentrations in the regenerating

216 phase $\left(1.1 \pm 0.2 \mu \mathrm{g} \mathrm{mg}^{-1}\right)$ as low as in the immature phase. Unlike in ovaries, TAG showed a pattern of

217 depletion in the liver through maturation (Fig. 3A). TAG levels decreased from PG $\left(7.8 \pm 0.2 \mu \mathrm{g} \mathrm{mg}^{-1}\right)$ to

$218 \operatorname{GVM}\left(1.7 \pm 0.5 \mu \mathrm{g} \mathrm{mg}^{-1}\right)$, and then increased significantly in the hydration stage $\left(7.0 \pm 0.6 \mu \mathrm{g} \mathrm{mg}^{-1}\right)$ to

219 reach maximum values in the regenerating phase $\left(7.9 \pm 0.2 \mu \mathrm{g} \mathrm{mg}^{-1}\right)$. As regards yellowfin tuna muscle,

220 ovarian maturation had no effect on TAG (Fig. 3A).

221

222 SE-WE followed the same patterns as TAG in yellowfin tuna gonads and muscle throughout maturation

223 (Fig. 3B). Muscle SE-WE concentrations were not significantly affected by ovarian maturation, while

224 gonad SE-WE values showed an accumulative pattern, that is, low values in PG and CA stages $(0.2 \pm 0.1$

$225 \mu \mathrm{g} \mathrm{mg}^{-1}$ and $0.3 \pm 0.1 \mu \mathrm{g} \mathrm{mg}^{-1}$, respectively), followed by a significant increase over vitellogenesis to reach

226 the maximum values in $\operatorname{Vtg} 3\left(5.1 \pm 0.2 \mu \mathrm{g} \mathrm{mg}^{-1}\right)$ and $\operatorname{GVM}\left(5.2 \pm 0.4 \mu \mathrm{g} \mathrm{mg}^{-1}\right)$, and finally a drastic

227 decrease during hydration $\left(0.4 \pm 0.5 \mu \mathrm{g} \mathrm{mg}^{-1}\right)$ and regenerating phases $\left(0.2 \pm 0.2 \mu \mathrm{g} \mathrm{mg}^{-1}\right)$. SE-WE showed

228 the opposite trend to TAG in the liver (Fig. 3B): concentrations were low and relatively constant from PG

$229\left(1.6 \pm 0.1 \mu \mathrm{g} \mathrm{mg}^{-1}\right)$ to $\operatorname{Vtg} 3\left(1.5 \pm 0.2 \mu \mathrm{g} \mathrm{mg}^{-1}\right)$, then increased significantly in GVM $\left(4.9 \pm 0.4 \mu \mathrm{g} \mathrm{mg}^{-1}\right)$ to

230 decrease again in hydration $\left(2.9 \pm 0.5 \mu \mathrm{g} \mathrm{mg}^{-1}\right)$ and further in the regenerating phase $\left(0.7 \pm 0.2 \mu \mathrm{g} \mathrm{mg}^{-1}\right)$.

231

232 PL also showed an accumulative pattern in the gonads (Fig. 3C) with a significant increase over the

233 vitellogenic process from $\operatorname{Vtg} 1\left(1.9 \pm 0.1 \mu \mathrm{g} \mathrm{mg}^{-1}\right)$ to $\operatorname{Vtg} 3\left(7.6 \pm 0.1 \mu \mathrm{g} \mathrm{mg}^{-1}\right)$, and a decrease from GVM

$234\left(6.6 \pm 0.3 \mu \mathrm{g} \mathrm{mg}^{-1}\right)$ to the regenerating phase $\left(2.2 \pm 0.1 \mu \mathrm{g} \mathrm{mg}^{-1}\right)$. In the liver, PL decreased significantly

235 from CA $\left(2.8 \pm 0.1 \mu \mathrm{g} \mathrm{mg}^{-1}\right)$ to GVM $\left(0.9 \pm 0.3 \mu \mathrm{g} \mathrm{mg}^{-1}\right)$, while concentrations increased during hydration

$236\left(3.6 \pm 0.3 \mu \mathrm{g} \mathrm{mg}^{-1}\right)$ to finally decrease again in the regenerating phase $\left(2.6 \pm 0.1 \mu \mathrm{g} \mathrm{mg}^{-1}\right)$. In the muscle, PL

237 concentrations decreased significantly from $\operatorname{Vtg} 1\left(3.3 \pm 0.1 \mu \mathrm{g} \mathrm{mg}^{-1}\right)$ to hydration $\left(1.0 \pm 0.3 \mu \mathrm{g} \mathrm{mg}^{-1}\right)$, then 
238 increased in the regenerating phase $\left(2.5 \pm 0.1 \mu \mathrm{g} \mathrm{mg}^{-1}\right)$ to reach levels similar to those in the immature

239 phase $\left(2.8 \pm 0.1 \mu \mathrm{g} \mathrm{mg}^{-1}\right)$ (Fig. 3C).

240

241 Despite very low levels, ST and AMPL in yellowfin tuna gonads followed the same pattern as the other

242 lipid classes (Fig. 3D and 3E). No significant effect of ovarian maturation was noted for ST and AMPL

243 concentrations in both yellowfin liver and muscle.

\subsection{Lipid class composition regarding fecundity estimates}

246 For BF analysis 9 females, ranging in size between 123 and $146 \mathrm{~cm}$ FL, were selected from the pool of

247 total samples. All of them were caught in free-swimming schools during the spawning period in 2009.

248 The estimated BF for these females ranged between 0.5 and 4.8 million eggs and the GSI was estimated

249 in $1.6 \pm 0.4$, HSI in $0.9 \pm 0.2$ and $\mathrm{K}$ in $1.7 \pm 0.1$. For NDO analysis 18 females were selected, ranging in size

250 from 88 to $145 \mathrm{~cm} \mathrm{FL} ; 3$ were caught in free-swimming schools and 5 under FADs, all of them during

251 the surveys performed in 2009. The estimated NDO ranged between 0.6 and 25.7 million oocytes. The

252 GSI for these females was estimated in $1.1 \pm 0.4$, HSI in $0.8 \pm 0.2$ and $\mathrm{K}$ in $1.9 \pm 0.2$.

253

254 According to the stepwise regression analysis between BF and the condition indices (Table 4), only GSI

255 was significantly correlated with $\mathrm{BF}\left(\mathrm{r}^{2}=0.75, P<0.05\right)$; regarding NDO, none of the condition indices

256 met the required 0.05 level of significance to get into the model. Investigation of the influence of the

257 tissue lipid composition on yellowfin tuna fecundity revealed that only TAG and SE-WE concentrations

258 in the muscle were related to BF, explaining $86 \%$ of the variation (Table 4), while in gonad and liver none

259 of lipid classes met the required 0.05 level of significance to get into the model. In contrast, the stepwise

260 regression analysis between lipid composition and NDO for the three tissues showed that only ST was

261 significantly correlated to NDO in gonads $\left(\mathrm{r}^{2}=0.40, P<0.05\right.$; Table 4$)$.

262

263 3.3. Lipid class composition regarding school types (FADs vs. free-swimming schools)

264 From the total pool of samples, 39 females were selected to assess lipid class composition regarding the

265 school types (Table 5): 25 females, ranging in size between 122 to $148 \mathrm{~cm}$ FL and in weight between 31

266 and $63 \mathrm{~kg}$, were caught in free-swimming schools and 14 females, ranging in size between 69 and $117 \mathrm{~cm}$

267 FL and in weight between 8.4 and $29 \mathrm{~kg}$, were caught under FADs. As shown in Table 6 and Fig. 4, the 
mixed ANCOVA model revealed a significant interaction between tissue and school type only for total lipids, PL and AMPL. In particular, higher total lipid and PL concentrations were measured in the gonads

270 of female yellowfin tuna caught in free-swimming schools (total lipids $=18.9 \pm 0.1 \mu \mathrm{g} \mathrm{mg}^{-1} ; \mathrm{PL}=6.1 \pm 0.1$

$\left.271 \mu \mathrm{g} \cdot \mathrm{mg}^{-1}\right)$ than in females caught under FADs (total lipids $\left.=12.6 \pm 0.2 \mu \mathrm{g} \mathrm{mg}^{-1} ; \mathrm{PL}=3.3 \pm 0.1 \mu \mathrm{g} \mathrm{mg}^{-1}\right)(P<$

272 0.05) (Fig. 4). In contrast, the school type did not seem to affect the liver and muscle lipid compositions.

273 As regards AMPL, a significant difference of liver concentrations was noted between females caught in

274 free-swimming schools $\left(1.7 \pm 0.1 \mu \mathrm{g} \mathrm{mg}^{-1}\right)$ and those caught under FADs $\left(1.0 \pm 0.1 \mu \mathrm{g} \mathrm{mg}^{-1}\right)$, while no

275 effect was observed for gonads and muscle.

276

277 4. Discussion

278 The life history strategy of yellowfin tuna has been described as "opportunistic" (Essington, 2003;

279 Fromentin and Fonteneau, 2001; Juan-Jorda et al., 2013) due to its early maturation, estimated around 75

$280 \mathrm{~cm}$ FL in the Western Indian Ocean ( $\mathrm{L}_{50}$, Zudaire et al., 2013b), rapid growth and high reproductive output (Schaefer et al., 2001). Accomplishing such a reproductive effort requires a high energetic

282 investment, and thus lipids and their constituent fatty acids are an essential source of nutrition providing a

283 significant amount of metabolic energy and structural components for developing oocytes, similar to

284 other tuna species (Mourente et al., 2002; Zaboukas et al., 2006). Saito et al. (1996) described that lipid composition of yellowfin tuna is mainly affected by the lipids of its prey and the environmental temperature (Saito et al., 1996). Despite the sampling strategy was fishery-dependent, female yellowfin tunas were collected covering the main two reproductive periods (Zudaire et al., 2013b). However, due to actual piracy problems along the study area, the sampling was conducted in two consecutive years, which could add inter-annual variability in terms of changes in environmental and tropich conditions affecting in some extend the results of the study.

\subsection{Lipid class composition along the reproductive cycle}

293 During fish ovarian development, the oocytes incorporate compounds essential for egg viability and

294 larval survival (Rainuzzo et al., 1997). In yellowfin tuna ovaries, all lipid classes (TAG, SE-WE, PL, ST

295 and AMPL) showed the same accumulative pattern through vitellogenesis; however, the observed

296 variability in the deposition of each lipid class may reflect their function during ovarian development

297 (Johnson, 2009). Similar to other fish species with oocytes containing oil globules (Kaitaranta and 
298 Ackman, 1981; Mourente et al., 2002; Ortega and Mourente, 2010), yellowfin tuna ovaries described a

299 predominance of neutral lipids (mainly TAG and SE-WE) over the polar lipids (PL and AMPL),

300 comprising $62 \%$ and $65 \%$ of the total lipids in the ovaries in Vtg3 and GVM stages, respectively. This

301 pattern is related to the role of neutral lipids as metabolic energy resources for oocyte formation.

302 Phospholipids also contributed significantly to total lipids in yellowfin tuna gonads (around 33\%) since it

303 plays a major role in cellular membranes and tissue formation (Tocher, 2003). Indeed, sufficient

304 quantities of both polar and neutral lipids are essential endogenous energetic resources for embryogenesis

305 and larvae development (Ortega and Mourente, 2010). However, in the present study, the gonads of

306 female yellowfin showed low total lipid contents (maximum mean value of $2.5 \%$ of gonad wet weight) in

307 comparison to other scombrids, being at least twofold lower than values observed in Thunnus tonggol

308 (Intarasirisawat et al., 2011), Sarda orientalis (Osako et al., 2009) and Katsuwonus pelamis (Hiratsuka et

309 al., 2004), and nearly fourfold lower than in Sarda sarda (Zaboukas et al., 2006). Species with

310 asynchronous oocyte development exhibit relatively low body energy investment in gamete formation

311 (Aristizabal, 2007), which explain the low observed gonad lipid contents regarding the high reproductive

312 output during the spawning season of yellowfin tuna (Zudaire et al., 2013b).

313

314 The decline of concentrations of the different lipid classes observed in the gonads at the hydration stage

315 probably results from a combination of two factors. First, the size of the oocytes increases significantly,

316 partly due to oocyte hydration (Wallace and Selman, 1981), a process that might contribute to the dilution

317 of the lipids in the ovaries. Indeed, a significant increase of the water content in the yellowfin tuna gonads

318 was observed between GVM $(71.6 \pm 2.3 \%)$ and hydration stages $(78.2 \pm 1.2 \%)$. Moreover, the process of

319 protein uptake into oocytes (i.e., Vtg and VLDL), which is also responsible for the lipid accumulation

320 stops abruptly at the time of germinal vesicle breakdown (Wallace and Selman, 1985).

321

322 The liver plays an important role in fish gonad development, being responsible for large lipid and fatty

323 acid deposits in the ovary, which are derived from prey and mobilized from the muscle during the

324 vitellogenesis process (Rinchard and Kestemont, 2003; Wiegand, 1996). When the liver is stimulated by

325 the ovary via estrogens, it starts to synthesise and secrete the two major sources of oocyte lipids: Vtg and

326 VLDL (Wiegand, 1996). In female yellowfin tuna, the liver showed two different patterns of lipid

327 acquisition and mobilization: TAG and PL showed depletion throughout ovarian development until the 
328 GVM stage, while SE-WE seemed to accumulate between the Vtg3 and GVM stages. Before

329 vitellogenesis occurred, the liver acted as a storage tissue for TAG and PL, with those lipid classes

330 representing $40 \%$ and $19 \%$ of total lipids in the liver, respectively. Hence, a large proportion of liver TAG

331 that was depleted through ovary development might have been transferred to the oocytes during

332 vitellogenesis and the GVM stage, which would explain the simultaneous increment of TAG found in

333 gonads during the maturation process. A similar process probably occurred with PL, although the largest

334 reduction was observed during the first stages of ovary maturation. The mobilization of PL from the liver

335 before vitellogenesis (between PG and Vtg1 stages) could correspond to a requirement of structural

336 compounds during early oocyte formation and/or energy substrate utilization for specific lipoprotein

337 synthesis, as previously noted in Sparus aurata (Almansa et al., 2001). On the other hand, the SE-WE

338 accumulative pattern could be related to an intensive lipid requirement of gonads due to the continuous

339 oocyte recruitment during the reproductive season; such an observation has already been made for the

340 multiple-batch spawner cyprinidae fishes (Rinchard and Kestemont, 2003). However, SE-WE increase

341 coincides with a major depletion of TAG at the GVM stage, and it could be hypothesized that the

342 variations of these two lipid classes are interrelated. A similar result was described by Norton and

343 MacFarlane (1999) for yellowtail rock (Sebastes flavidus) fish, in which the increase of PL was due to a

344 depletion of TAG in the liver during the vitellogenesis process.

345

346 The white muscle of female yellowfin tuna was characterized by very low total lipid contents (maximum

347 mean value of $0.6 \%$ wet weight in PG stage females), which is in accordance with previous estimations

348 for this species (Medina et al., 1995; Saito et al., 1996) as well as other types of tuna such as Thunnus

349 obesus, Auxis thazard and Katsuwonus pelamis (muscle total lipids: $0.8 \%, 0.6 \%$ and $0.8 \%$, respectively;

350 Medina et al., 1995), as well as Sarda orientalis (muscle total lipids: 0.8\%-0.9\%; Osako et al., 2009). No

351 significant variations of lipid class concentrations were noted in the muscle through the reproductive

352 cycle, with the exception of PL, which decreased during vitellogenesis. In contrast, other types of tuna

353 like bluefin tuna (Thunnus thynnus) (Mourente et al., 2002) and bonito (Sarda sarda) (Zaboukas et al.,

354 2006) have been described to accumulate larger lipid deposits in somatic tissues (muscle, mesenteric

355 perigonadal tissue), with a predominance of neutral lipids. In these temperate species, the stored lipid

356 reserves are devoted either to cover the requirements of high metabolic activity or for reproduction,

357 corresponding to the particular energy allocation strategy used. 
359 Yellowfin tuna exhibited a low capacity for energy storage through the reproductive cycle and showed

360 very low lipid contents in gonads compared to other tunas, which can be a sign of a strategy of low

361 energy allocation of this tuna species for the reproduction. . Yellowfin tuna exhibits indeterminate

362 fecundity and asynchronous oocyte development (Zudaire et al., 2013a), and females feed intensively

363 throughout the reproductive cycle (Itano, 2000; Zudaire in prep). All these lines of evidence together with

364 the absence of a substantial endogenous source of energy for ovarian development make this species a

365 suitable candidate to be considered as a pure income breeder (McBride et al., 2013; Alonso-Fernández et

366 al., 2012). However, the lipid allocation pattern shown by the liver, accumulating certain lipids (TAG and

367 PL) prior to vitellogenesis, could suggest that yellowfin tuna exhibits an intermediate strategy (income-

368 capital breeder) in which, despite the priority of energy allocation from feeding, the energy stored before

369 reproduction is also required for successful reproduction (Henderson and Morgan, 2002). Species that

370 feed intensively through ovarian maturation incorporate more dietary lipids for oocyte development

371 (Johnson, 2009), and thus the availability of food during the spawning season could greatly modulate the

372 reproductive investment and condition the manner in which stored energy is used to offset the cost of

373 reproduction (Aristizabal, 2007).

374

375 The length of yellowfin tuna exhibited positive relationships with TAG and TAG/ST ratio in the ovaries,

376 although the coefficients of determination for both relationships were low. The increase of lipid

377 concentration with female size was previously described for other fish species in which the size of the

378 female could boost the lipid deposition to oocytes (Wiegand et al., 2007). Moreover, a significant

379 negative relationship was observed between total lipid and FL in muscle. These patterns observed in

380 gonads and muscle could explain the physiological changes and associated energy requirements and

381 partitioning during the ontogeny of yellowfin tuna reflected in different reproductive allocation patterns,

382 and they might be related to the energy balance between somatic growth and gonadic growth, which is

383 size-dependent (Claramunt et al., 2007). Thus, a larger amount of lipid in the muscle of smaller (younger)

384 individuals could reflect an increase in energy investment for somatic growth, while older and larger

385 females could invest higher levels of energy through lipid reserves for gonadic growth as future

386 reproductive opportunities decline (Wiegand et al., 2007).

387 
389 Maternal condition and quantity of reserves in particular, are believed to limit reproductive potential

390 through fecundity in some species (Johnson, 2009; Marshall et al., 1999; Wiegand et al., 2007). Studies

391 with cultured (Margulies et al., 2007) and wild (Itano, 2000) female yellowfin tuna provided evidence of

392 a positive relationship between the feeding rate and fecundity. In the present study, although the fecundity

393 estimates (BF and NDO) and lipid classes did not show consistent relationships in ovary and liver, a

394 correlation between BF and muscle TAG and SE-WE was found. The high percentage of BF variability

395 explained by TAG and SE-WE in muscle contrasted with the fact that total lipids in yellowfin tuna

396 muscle exhibited small variations during maturation, and it could be explained as an artefact of the low

397 number of samples used for this analysis. On the other hand, the higher proportion of lipid reserves in the

398 muscle of spawning-capable females may indicate that these fishes were in a better condition which can

399 be translated into a higher fecundity rate as suggested by Schaefer (1998). This strategy is more common

400 for capital breeders species inhabiting temperate water like bluefin tuna (Chapman et al., 2011; Mourente

401 et al., 2002), which have a particularly intense feeding season before the reproductive period. In these

402 species certain somatic tissues, namely, muscle and/or mesenteric perigonadal tissues, exhibit increases in

403 their lipid reserves to be used later during the reproductive cycle. The prediction of fish fecundity through

404 study of maternal condition was described less accurate in income breeder species (Kjesbu, 2009), due to

405 the modulation of reproductive investment is more instantaneously linked to food availability and thus it

406 is more difficult to assess using condition indices. Thus, further research on a greater number of samples

407 and including an analysis of energetic compounds important for reproduction (Kjesbu, 2009) is required

408 to obtain a better overview of factors affecting fecundity in yellowfin tuna.

409

410 4.3. Lipid class composition regarding school types (FADs vs. free-swimming schools)

411 Several studies hypothesized that FADs could affect tuna movement and migration, leading them to low-

412 quality habitats, with potentially detrimental effects on individual and population conditions (Hallier and

413 Gaertner, 2008; Marsac et al., 2000). The lipid composition of yellowfin tuna has been observed to be

414 affected by the environmental conditions and feeding quality (Saito et al., 1996). In the present study,

415 female yellowfin tuna caught in free-swimming schools had higher concentrations of total lipids and PL

416 in the gonads and AMPL in the liver than those caught under FADs. Moreover, higher TAG/ST ratios

417 were observed in the gonads of females caught in free-swimming schools. These results might suggest a 
418 higher energetic investment in the gonads of females caught in free-swimming schools, and could be

419 interpreted as a sign of these fishes being in a better condition than those caught under FADs. The higher

420 feeding success associated with females in free-swimming schools (Jaquemet et al., 2011) could provide

421 them with larger amounts of energy (e.g., lipids) for reproductive investment. This fact is especially

422 important for species performing income-capital strategy, since the concurrent income energy from

423 feeding is essential for tuning the reproductive effort (McBride et al., 2013). However, the difference in

424 the range of size of sampled individuals between females in free-swimming schools and females under

425 FADs could be a factor affecting the lipid concentration by itself and thus a source of bias. Besides, the

426 absence of a significant relationship between gonad lipids and fecundity suggests that there is no

427 established minimum lipid concentration threshold, indicating that the lower lipid content of FADs

428 females may not jeopardize current reproduction.

429

430 Detailed information on the residence time of the females analysed at FADs is lacking in this study. Data

431 of residence time would allow us to assess whether the suggested detriment of feeding success at FADs

432 (Jaquement et al., 2011) affects lipid acquisition and, hence, individual and population productivity.

433 Therefore, further analyses of fish condition (morphometric and biochemical) based on a better sampling

434 strategy that accounts for school type are required to avoid bias and uncertainty in the sampling, such as

435 geographical and temporal effects, which can affect either the environmental conditions and/or

436 reproductive effort of the species.

437

\section{5. Conclusions}

439 The results provide evidences that the heterogeneity of lipid contents among tissues and the provisioning

440 of lipids for reproduction are related to the reproductive strategy and the role of those tissues during

441 reproduction, as it was observed for other fish species (Johnson, 2009). Yellowfin tuna exhibited a

442 strategy of low energy allocation before reproduction, which was mainly based on lipids stored in the

443 liver. The lack of substantial endogenous energy investment for ovarian development regarding the low

444 lipid content found in tissues could suggest that yellowfin tuna rely, to a large extent, on concurrent

445 energy income from feeding to finance the cost of reproduction. Thus, regarding the combined use of

446 stored lipids and concurrent income energy from prey, together with the reproductive strategy of

447 yellowfin tuna (i.e., asynchronous and indeterminate fecundity), it could be considered that this species is 

energetic compounds, such as proteins, which would provide a fuller understanding of the energy dynamics during reproduction. In addition, studies of feeding throughout the reproductive cycle are needed to assess variations in the energy supply from prey. Prey availability prior to and during the reproductive cycle will condition the amount of energy stored prior to reproduction and/or the manner in which energy resources are used to offset the cost of reproduction.

454 Finally, although the lipid composition of the main tissues (gonad and liver) involved in reproduction in yellowfin tuna were not strongly correlated with fecundity in this study, food availability is likely to constitute a limiting factor for reproductive potential. Thus, precise characterisation of this relationship of endogenous and income energy supply with fecundity is needed to reveal the impact of abiotic factors such as FADs on the reproductive potential of yellowfin tuna populations.

\section{Acknowledgements} samples, and I. Gomez, M. Cuesta and I. Martin for their assistance with planning the sampling materials. We greatly appreciate the assistance of J. Murua, G. Ocio and Antonio for sample collections on board the purse seiner. This research benefited from the financial support of the Department of Agriculture, Fisheries and Food of the Basque Government, and the Pesquería Vasco Montañesa S.A. (PEVASA) fishing company. This work was partly funded by a PhD grant from the Fundación Centros Tecnológicos Iñaki Goenaga to Iker Zudaire. We are also grateful for the contribution received from EMOTION project (ANR JSV7 007 01). The experiments complied with the current laws of the countries in which they were performed. The authors declare that they have no conflicts of interest. This paper is contribution $\mathrm{n}^{\mathrm{o}} \mathrm{xxxx}$ from AZTI-Tecnalia (Marine Research Department).

\section{References}

473 Almansa, E., Martín, M.V., Cejas, J.R., Badía, P., Jerez, S., Lorenzo, A., 2001. Lipid and fatty acid composition of female gilthead seabream during their reproductive cycle: effects of a diet lacking n-3 HUFA. J. Fish Biol. 59, 267-286. 
Aristizabal, E.O., 2007. Energy investment in the annual reproduction cycle of female red porgy, Pagrus pagrus (L.). Mar. Biol. 152(3), 713-724.

Bertrand, A., Bard, F.X., Josse, E., 2002. Tuna food habits related to the micronekton distribution in French Polynesia. Mar. Biol. 140, 1023-1037.

Chapman, E.W., Jorgensen, C., Lutcavage, E., 2011. Atlantic bluefin tuna (Thunnus thynnus): a statedependent energy allocation model for growth, maturation, and reproductive investment. Can. J. Fish. Aquat. Sci. 68,1934-1951.

Claramunt, G., Serra, R., Castro, L.R., Cubillos, L., 2007. Is the spawning frequency dependent on female size? Empirical evidence in Sarinops sagax and Egraulis ringens off northern Chile. Fish. Res. $85,248-257$.

Collette, B.B., Nauen, C.E., 1983. FAO Species Catalogue. Vol . 2 : Scombrids of the World: An Annotated and Illustrated Catalogue of Tunas, Mackerels, Bonitos, and Related Species Known to Date. FAO, Rome. 137 pp. (Fish. Synop. 125).

Dagorn, L., Holland, K.N., Itano, D.G., 2007. Behavior of yellowfin (Thunnus albacares) and bigeye (Thunnus obesus) tuna in a network of fish aggregating devices (FADs). Mar. Biol. 151, 595606.

Dagorn, L., Holland, K.N., Restrepo, V., Moreno, G., 2012. Is it good or bad to fish with FADs? What are the real impacts of the use of drifting FADs on pelagic marine ecosystems? Fish Fish.

Essington, T.E., 2003. Development and sensitivity analysis of bioenergetics models for skipjack tuna and albacore: A comparison of alternative life histories. Trans. Am. Fish. Soc. 132, 759-770.

Folch, J., Less, M., Sloane, G.H., Stanley, 1957. A simple method for the isolation and purification of total lipids from animal tussues. J. Biol. Chem. 226, 497.

Fromentin, J.M., Fonteneau, A.., 2001. Fishing effects and life history traits: a case study comparing tropical versus temperate tunas. Fish. Res. 53, 133-150.

Hallier, J.P., Gaertner, D., 2008. Drifting fish aggregation devices could act as an ecological trap for tropical tuna species. Mar. Ecol. Prog. Ser. 353, 255-264.

Henderson, B.A., Morgan, G.E., 2002. Maturation of walleye by age, size and surplus energy. J. Fish Biol. 61 (4), 999-1011.

Henderson, B.A., Wong, J.L., Nepszy, S.J., 1996. Reproduction of walleye in Lake Erie: allocation of energy. Can. J. Fish. Aquat Sci. 53, 127-133. 
Henderson, B.A., Wong, J.L., 1998. Control of lake trout reproduction: role of lipids. J. Fish Biol. 52, 1078-1082.

510 Hiratsuka, S., Kitagawa, T., Matsue, Y., Hashidume, M., Wada, S., 2004. Lipid class and fatty acid composition of phospholipids from the gonads of skipjack tuna. Fish. Sci. 70, 903-909.

Houston, A.I., Stephens, P.A., Boyd, I.L., Harding, K.C., McNamara, J.M., 2006. Capital or income breeding? A theoretical model of female reproductive strategies. Behav. Ecol. 18, 241-250.

Hunter, J.R., Macewicz. B.J., Kimbrell, C.A., 1989. Fecundity and other aspects of the reproduction Sablefish, Anoplopoma fimbria, in Central California water. California Cooperative Oceanic Fish. Investig. Rep.. 30. p. 61-72.

Intarasirisawat, R., Benjakul, S., Visessanguan, W., 2011. Chemical compositions of the roes from skipjack, tongol and bonito. Food Chem. 124, 1328-1334.

IOTC (Indian Ocean Tuna Commission), 2012. Report of the fifteenth session of the IOTC Scientific Committee. Victoria, Seychelles. IOTC Secretariat, P.O. Box 1011, Victoria, Seychelles.

Itano, D.G., 2000. The reproductive biology of yellowfin tuna (Thunnus albacares) in Hawaiian water and the western tropical Pacific Ocean: Project summary. PFRP, JIMAR, UH, HI. pp. 69 (Contribution 00-328)

Izquierdo, M.S., Fernández-Palacios, H., Tacon A.G.J., 2001. Effect of broodstock nutrition on reproductive performance of fish. Aquaculture. 197, 25-42.

Jaquemet, S., Potier, M., Ménard, F., 2011. Do drifting and anchored Fish Aggregating Devices (FADs) similarly influence tuna feeding habits? A case study from the western Indian Ocean. Fish. Res. $107,283-290$.

Johnson, R.B., 2009. Lipid deposition in oocytes of teleost fish during secondary oocyte growth. Rev. Fish. Sci. 17(1), 78-89.

Juan-Jorda, M.J., Mosqueira, I., Freire, J., Dulvy, K. 2013. Life in 3-D: life history strategies in tunas, mackerels and bonitos. Rev. Fish Biol. Fish. 23(2), 135-155.

Kaitaranta, J.K., Ackman R.G., 1981. Total lipids and lipid classes of fish roe. Comp. Biochem. Physiol. 69B, 725-729.

Kjesbu, O.S., 2009. Applied fish reproductive biology: contribution of individual reproductive potential to recruitment and fisheries management, in: Jokobsen,T., Fogarty, J., Megrey, B., Moksness, E. 

Blackwell, United Kingdom, pp. 293-332.

Kjesbu, O. S., Witthames, P. R., Solemdal, P., Greer Walker, M., 1998. Temporal variations in the fecundity of Arcto-Norwegian cod (Gadus morhua) in response to natural changes in food and temperature. J. Sea Res. 40, 303-321.

Margulies, D., Suter, J.M., Hunt, S.L., Olson, R.J., Scholey, V.P., Wexler, J.B., Nakazawa, A., 2007. Spawning and early development of captive yellowfin tuna (Thunnus albacares). Fish. Bull. 105, 249-265.

Marsac, F., Fonteneau, A., Menard, F., 2000. Drifting FADs used in tuna fisheries: and ecological trap? In: Pêche thoniere et dispositifs de concentration de poisons (proceedings of the 1st Symposium on Tuna fisheries and FADs, Martinique, October 1999). (eds J.Y. Le Gal, P. Cayre' and M. Taquet). Actes Colloques-IFREMER. 28, 537-552.

Marshall, C.T., Yaragina, N.A., Lambert, Y., Kjesbu, O.S., 1999. Total lipid energy as a proxy for total egg production by fish stocks. Nature. 402 (6759), 288-290. Fernández, A., Basilone, G., 2013. Energy acquisition and allocation to egg production in relation to fish reproductive strategies. Fish Fish. .

McPherson, G.R., 1991. Reproductive biology of yellowfin tuna in the eastern Australian fishing zone, with special reference to the North-western Coral Sea. Aust. J. Mar. Freshw. Res., 42, 465-477.

Medina, I., Santiago, P., Aubourg, P., Martin, R.P., 1995. Composition of Phospholipids of White Muscle of Six Tuna Species. Lipids. 30, 1127-1135.

Mourente, G., Megina, C., Díaz-Salvago, E., 2002 Lipids in female northern bluefin tuna (Thunnus thynnus thynnus L.) during sexual maturation. Fish Physiol. Biochem. 24, 351-363, 2002.

Murua, M., Motos, L., 2006. Reproductive strategy and spawning activity of the European hake Merluccius merluccius (L.) in the Bay of Biscay. J. Fish Biol. 69, 1288-1303.

Norton, E.C., MacFarlane, R.B., 1999. Lipid class composition of the viviparous yellowtail rockfish over a reproductive cycle. J. Fish. Biol. 54,1287-1299.

Ortega, A., Mourente, G., 2010. Comparison of the lipid profiles from wild caught eggs and unfed larvae of two scombroid fish: northern bluefin tuna (Thunnus thynnus L., 1758) and Atlantic bonito (Sarda sarda Bloch, 1793). Fish Physiol. Biochem. 36, 461-471. 
Osako, K., Saito, H., Weng, W., Kuwahara, K., Tanaka, M., 2009. Lipids characteristics of coastal migratory Sarda orientalis tissues. Fish Sci. 75,1055-1066.

Parrish, C.C., 1999. Determination of total lipid, lipid classes, and fatty acids in aquatic samples. In: Lipids in Freshwater Ecosystems (ed. Arts, M.T., Wainman, B.C.). New York: Springer-Verlag. pp. $5-20$

Rainuzzo, J.R., Reitan, K.I., Olsen, Y., 1997. The significance of lipids at early stages of marine fish: a review. Aquaculture. 155, 103-115.

Rinchard, J., Kestemont, P., 2003. Liver changes related to oocyte growth in roach, a single spawner fish, and in bleak and white bream, two multiple spawner fish. Internat. Rev. Hydrobiol. 88, 68-76.

Saito, H., Ishihara, K., Murase, T., 1996. Effect of prey fish lipids on the docosahexaenoic acid content of total fatty acids in the lipid of Thunnus albacares yellowfin tuna. Biosci. Biotech. Biochem. 60(6), 962-965.

Sargent, J.R., 1995. Origins and functions of lipids in fish eggs: nutritional implications. In: Broodstock Management and Egg and Larval Quality. Bromage, N.R., Roberts, R.R., Eds. Oxford: Blackwell Science. pp. 353-372.

Sargent, J.R., Tocher, D.R., Bell, J.G., 2002. The lipids. In: Fish Nutrition, 3rd Ed., Ch.4. (Halver, J. E., Ed.). San Diego: Acad. Press. pp. 181-257.

Schaefer, K.M., 1996. Spawning time, frequency, and batch fecundity of yellowfin tuna, Thunnus albacares, near Clipperton Atoll in the eastern Pacific Ocean. Fish. Bull. 94, 98-112.

Schaefer, K.M., 1998. Reproductive biology of yellowfin tuna (Thunnus albacares) in the eastern Pacific Ocean. Inter-Am. Trop. Tuna Commun., Bull., 21(5), 205-221.

Schaefer, K.M., 2001. Reproductive biology of tunas. In: Block, B.A., Stevens, E.D. (Eds.), Tuna: Physiology, ecology, and evolution. Acad. Press, San Diego, California, US. pp. 225-270.

Schaefer, K.M., and Fuller, D.W., 2010. Vertical movements, behavior, and habitat of bigeye tuna (Thunnus obesus) in the equatorial eastern Pacific Ocean, ascertained from archival tag data.

593 Stearns, S.C., 1992. The Evolution of Life Histories. New York: Oxford University Press.

594 Stéquert, B., Nuñez, J., Cuisset, B., Le Menn, F., 2001. Gonadosomatic index and seasonal variations of plasma sex steroids in skipjack tuna (Katsuwonus pelamis) and yellowfin tuna (Thunnus albacares) from the western Indian Ocean. Aquat. Liv. Resour. 14, 313-318. 
Tocher, D.R., 2003. Metabolism and functions of lipids and fatty acids in teleost fish. Rev. Fish. Sci. 11(2) 107-184.

Wallace, R.A., Selman, K., 1981. Cellular and dynamic aspects of oocyte growth in teleosts. Am. Zool. $21,325-343$.

601

Wallace, R.A., Selman, K., 1985. Mayor protein changes during vitellogenesis and maturation of fundulus oocyte. Dev. Biol. 110(2), 492-498.

Wiegand, M.D. 1996. Composition, accumulation and utilization of yolk lipids inteleost fish. Rev. Fish Biol. Fish. 6, 259-286.

Wiegand, M.D., Johnston, T.A., Leggett, W.C., Watchorn, K.E., Ballevona, A.J., Porteous, L.R., Casselman, J.M., 2007. Contrasting strategies of ova lipid provisioning in relation to maternal characteristics in three walleye (Sander vitreus) populations. Can. J. Fish. Aquat. Sci. 64, 700712.

609

Zaboukas, N., Miliou, H., Megalofonou, P., Moratiou-Apostolopoulou, M., 2006. Biochemical

610 composition of the Atlantic bonito Sarda sarda from the Aegean Sea (eastern Mediterranean Sea) in different stages of sexual maturity. J. Fish Biol. 69, 347-362.

612 Zhu, G., Xu, L., Zhou, Y., Song, L., 2008. Reproductive biology of yellowfin tuna (T. albacares) in the west-central Indian Ocean. J. Ocean Univ. China (Engl. Ed.). 7, 327-332.

614 Zudaire, I., Murua, H., Grande, M., Korta, M., Arrizabalaga, H., Areso, J.J., Delgado-Molina, A., $2013 a$.

615

616 Yellowfin tuna (Thunnus albacares) fecundity regulation strategy in the Western Indian

617 Ocean. Fish. Res. 138, 80-88.

618

Zudaire, I., Murua, H., Grande, M., Bodin, N., 2013b. Reproductive potential of the yellowfin tuna

619

620

621

622

623

624

625

626 
628 Table 1. Summary of yellowfin tuna samples collected in the Western Indian Ocean during the three

629 surveys (first survey: from January to March 2009; second survey from June to July 2009; third survey

630 from April to May 2010) by school types (fish aggregating devices [FADs] and free-swimming school

631 [FREE]). Range of fork length (FL) and range of total weight $(\mathrm{W})$ is provided. The collected samples are

632 shown by survey and by ovarian development phases (Dev. Phase): IP = immature phase; DP =

633 developing phase; $\mathrm{SCP}=$ spawning-capable phase and $\mathrm{RP}=$ regenerating phase.

634

635

\begin{tabular}{lccc}
\hline & 2009 & 2010 \\
\hline $1^{\text {st }}$ Survey & $2^{\text {nd }}$ Survey & $3^{\text {rd }}$ Survey \\
\hline
\end{tabular}

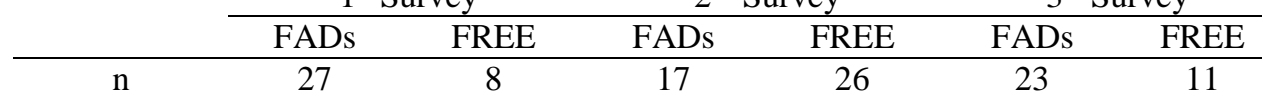

$\begin{array}{llllll}\text { FL range } \quad 50-110 & 123-153 & 56-118 & 122-148 & 60-120 & 56-112\end{array}$

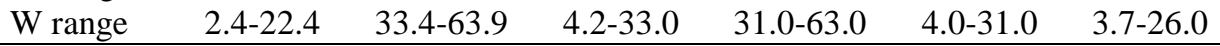

\begin{tabular}{lcccccc}
\hline Dev. Phase & & & & & & \\
\hline IP & 8 & -- & 2 & -- & 9 & 3 \\
DP & 16 & -- & 13 & 12 & 6 & 4 \\
SCP & 3 & 8 & 2 & 14 & -- & -- \\
RP & -- & -- & -- & -- & 8 & 4 \\
\hline
\end{tabular}

636

637

638

639

640

641

642

643

644

645

646

647

648

649

650

651 
653 Table 2. Mean ( \pm SE) of condition indices (gonadosomatic index GSI, hepatosomatic index HSI, and

654 condition factor $\mathrm{K})$ and total lipid (TL) concentrations ( $\left.\mu \mathrm{g} \cdot \mathrm{mg}^{-1} \mathrm{ww}\right)$ in the gonads, liver and white

655 muscle of female yellowfin tunas collected at different ovarian development phases (Dev. Phase) in the

656 Western Indian Ocean. The number of samples (n) and the fish size range $(\mathrm{cm})$ are specified. Four

657 ovarian development phases were distinguished: IP = immature phase including the primary growth stage

658 (PG); DP = developing phase including the cortical alveoli $(\mathrm{CA})$, primary vitellogenesis $(\mathrm{Vtg} 1)$ and

659 secondary vitellogenesis ( $\mathrm{Vtg} 2) ; \mathrm{SCP}=$ spawning-capable phase including the tertiary vitellogenesis

660 (Vtg3), germinal vesicle migration (GVM) and hydration (HYD) stages; RP = regenerating phase.

661

\begin{tabular}{clcccccccc}
\hline Dev. Phase. & Dev. Stage & $\mathrm{n}$ & FL range & GSI & HSI & K & TL Gonads & TL Liver & TL Muscle \\
\hline IP & PG & 22 & $50-109$ & $0.2 \pm 0.1$ & $1.0 \pm 0.3$ & $2.0 \pm 0.2$ & $6.5 \pm 0.1$ & $20.8 \pm 0.1$ & $5.9 \pm 0.1$ \\
DP & CA & 35 & $50-145$ & $0.3 \pm 0.1$ & $0.8 \pm 0.3$ & $1.9 \pm 0.2$ & $4.8 \pm 0.1$ & $16.2 \pm 0.1$ & $4.9 \pm 0.1$ \\
& Vtg1 & 8 & $76-148$ & $0.6 \pm 0.3$ & $0.7 \pm 0.2$ & $1.9 \pm 0.3$ & $7.3 \pm 0.2$ & $14.2 \pm 0.2$ & $5.3 \pm 0.2$ \\
& Vtg2 & 8 & $69-146$ & $0.7 \pm 0.3$ & $0.7 \pm 0.1$ & $2.0 \pm 0.3$ & $13.2 \pm 0.2$ & $14.3 \pm 0.2$ & $4.4 \pm 0.2$ \\
SCP & Vtg3 & 18 & $88-145$ & $1.1 \pm 0.5$ & $0.8 \pm 0.2$ & $2.0 \pm 0.3$ & $26.7 \pm 0.2$ & $13.7 \pm 0.2$ & $5.3 \pm 0.2$ \\
& GVM & 5 & $123-146$ & $1.7 \pm 0.4$ & $1.0 \pm 0.1$ & $1.7 \pm 0.0$ & $25.8 \pm 0.4$ & $10.3 \pm 0.4$ & $3.4 \pm 0.4$ \\
& HYD & 4 & $130-153$ & $1.4 \pm 0.6$ & $1.1 \pm 0.1$ & $1.8 \pm 0.0$ & $11.6 \pm 0.4$ & $19.8 \pm 0.4$ & $2.9 \pm 0.5$ \\
RP & & 12 & $102-120$ & $0.3 \pm 0.1$ & $0.7 \pm 0.1$ & $1.9 \pm 0.1$ & $5.2 \pm 0.2$ & $17.2 \pm 0.2$ & $4.4 \pm 0.2$ \\
\hline
\end{tabular}

662

663

664

665

666

667

668

669

670

671

672

673

674

675

676

677 
679 Table 3. Summary of the mixed ANCOVA model ( $P$-values) on the effects of the female yellowfin

680 maturity (i.e., ovarian developmental phases and stages) on the concentrations of total lipids and lipid

681 classes in three tissues (gonads, liver and muscle). Results of the interactions between the tissues,

682 condition indices (GSI = gonadosomatic index; HIS = hepatosomatic index; K = condition factor) and

683 fork length $(\mathrm{FL})$ are provided. TAG = triacylglycerols; $\mathrm{SE}-\mathrm{WE}=$ sterol- and wax-esters; PL =

684 phospholipids; ST = sterols; $\mathrm{AMPL}=$ acetone mobile polar lipids; $\mathrm{KET}=$ ketones.

685

686

\begin{tabular}{lccccccc}
\hline & TAG & SEWE & PL & ST & AMPL & KET & Total Lipids \\
\hline Maturity & $\mathbf{0 . 0 2 9}$ & $\mathbf{0 . 0 0 4}$ & $\mathbf{0 . 0 3 8}$ & 0.074 & 0.547 & 0.401 & $\mathbf{0 . 0 0 9}$ \\
Tissue & $\mathbf{0 . 0 0 4}$ & 0.360 & 0.616 & $\mathbf{0 . 0 2 3}$ & $\mathbf{0 . 0 1 5}$ & 0.746 & $\mathbf{0 . 0 2 3}$ \\
FL*Tissue & $<\mathbf{0 . 0 0 1}$ & 0.514 & 0.199 & $\mathbf{0 . 0 0 3}$ & $\mathbf{0 . 0 0 2}$ & 0.058 & $<\mathbf{0 . 0 0 1}$ \\
GSI*Tissue & 0.801 & 0.292 & 0.348 & 0.564 & 0.863 & 0.829 & 0.997 \\
HSI*Tissue & $<\mathbf{0 . 0 0 1}$ & 0.150 & 0.559 & $\mathbf{0 . 0 0 9}$ & 0.659 & $\mathbf{0 . 0 0 2}$ & $\mathbf{0 . 0 0 1}$ \\
K*Tissue & 0.066 & 0.073 & 0.755 & 0.325 & 0.055 & 0.976 & 0.165 \\
Maturity*Tissue & $\mathbf{0 . 0 0 2}$ & $<\mathbf{0 . 0 0 1}$ & $<\mathbf{0 . 0 0 1}$ & $\mathbf{0 . 0 1 4}$ & $\mathbf{0 . 0 1 6}$ & 0.360 & $<\mathbf{0 . 0 0 1}$ \\
\hline
\end{tabular}

687

688

689

690

691

692

693

694

695

696

697

698

699

700

701

702

703

704 
706 Table 4. Summary of the significant results of the stepwise regression model selection between (i) the 707 muscle lipid composition and the batch fecundity (BF) and the gonad lipid composition and number of 708 developing oocyte (NDO) of yellowfin tuna, (ii) fish condition and batch fecundity (BF). GSI =

709 gonadosomatic index; TAG = triacylglycerols; SE-WE = sterol- and wax-esters; ST = sterols.

710

711

\begin{tabular}{rccccc}
\hline Lipid composition & Step & Variable & $\mathrm{r}^{2}$ & $F$-value & $P$-value \\
\hline BF & 1 & TAG & 0.644 & 12.67 & 0.009 \\
& 2 & SEWE & 0.217 & 9.37 & 0.022 \\
\cline { 2 - 6 } NDO & 1 & ST & 0.410 & 11.10 & 0.004 \\
\hline Condition Indices & Step & Variable & $\mathrm{r}^{2}$ & F-value & P-value \\
\hline BF & 1 & GSI & 0.755 & 18.47 & 0.005 \\
\hline
\end{tabular}

712

713

714

715

716

717

718

719

720

721

722

723

724

725

726

727

728

729

730

731 
733 Table 5. Summary of yellowfin tuna females at developing and spawning-capable phases included in the

734 analysis of the effects of the school-type on the concentrations of total lipids and lipid classes in three

735 tissues (gonads, liver and muscle). The number of samples (n), the fork length range (FL; $\mathrm{cm})$, and weight

736 range $(\mathrm{W} ; \mathrm{kg})$ are specified. Mean $( \pm \mathrm{SE})$ of condition indices (gonadosomatic index GSI, hepatosomatic

737 index HSI, and condition factor K) and total lipid (TL) concentrations ( $\left.\mu \mathrm{g} \cdot \mathrm{mg}^{-1} \mathrm{ww}\right)$ in the gonads, liver

738 and white muscle are provided.

739

\begin{tabular}{lccccccccc}
\hline School-type & $\mathrm{n}$ & FL range & W range & GSI & HSI & K & TL Gonads & TL Liver & TL Muscle \\
\hline FADs & 14 & $69-117$ & $8.5-29$ & $0.6 \pm 0.4$ & $0.9 \pm 0.3$ & $2.1 \pm 0.2$ & $12.6 \pm 0.2$ & $12.7 \pm 0.2$ & $5.3 \pm 0.2$ \\
FREE & 25 & $122-148$ & $31-63$ & $1.2 \pm 0.5$ & $0.8 \pm 0.2$ & $1.9 \pm 0.3$ & $18.9 \pm 0.1$ & $17.4 \pm 0.1$ & $3.7 \pm 0.1$ \\
\hline 740
\end{tabular}

740

741

742

743

744

745

746

747

748

749

750

751

752

753

754

755

756

757

758

759

760 
762 Table 6. Summary of the mixed ANCOVA model ( $P$-values) on the effects of the school-type on the

763 concentrations of total lipids and lipid classes in three tissues (gonads, liver and muscle) of the yellowfin

764 tuna. Results of the interactions between the tissue and the school-type (FADs and free-swimming school)

765 are provided. TAG $=$ triacylglycerols; $\mathrm{SE}-\mathrm{WE}=$ sterol- and wax-esters; $\mathrm{PL}=$ phospholipids; $\mathrm{ST}=$ sterols;

766 AMPL = acetone mobile polar lipids; KET $=$ ketones.

767

768

\begin{tabular}{lccccccc}
\hline & TAG & SEWE & PL & ST & AMPL & KET & Total Lipids \\
\hline School-type & 0.434 & 0.408 & $\mathbf{0 . 0 3 3}$ & 0.683 & 0.198 & 0.743 & 0.233 \\
Tissue & $<\mathbf{0 . 0 0 1}$ & $\mathbf{< 0 . 0 0 1}$ & $\mathbf{< 0 . 0 0 1}$ & $\mathbf{< 0 . 0 0 1}$ & $<\mathbf{0 . 0 0 1}$ & $<\mathbf{0 . 0 0 1}$ & $<\mathbf{0 . 0 0 1}$ \\
School-type*Tissue & 0.101 & 0.373 & $\mathbf{0 . 0 0 2}$ & 0.719 & $\mathbf{0 . 0 3 8}$ & 0.487 & $\mathbf{0 . 0 1 6}$ \\
\hline
\end{tabular}

769

770

771

772

773

774

775

776

777

778

779

780

781

782

783

784

785

786

787

788 


\section{$790 \quad$ Figure caption}

791 Fig. 1 The locations at which female yellowfin tuna (Thunnus albacares) were sampled in the Western

792 Indian Ocean during 2009 and 2010 by school type: free-swimming schools (+) and fish aggregating

793 devices (FADs) (•).

794 Fig. 2 Significant linear regressions $(p<0.05)$ derived from the mixed ANCOVA model between

795 yellowfin tuna fork length (FL, cm) and (A) gonad triacylglycerol (TAG) concentration, (B) gonad

796 triacylglycerol:sterol (TAG/ST) ratio and (C) muscle total lipid (cTotal) concentration, as well as between

797 the hepatosomatic index (HSI) and liver TAG/ST ratio (D).

798 Fig. 3 Concentrations ( $\mu$ g. $\mathrm{mg}^{-1}$ ww) of (A) triacylglycerols (TAG), (B) sterol- and wax-esters (SE-WE),

799 (C) phospholipids (PL), (D) sterols (ST), (E) acetone mobile polar lipids (AMPL) and (F) total lipids in

800 the gonads $(\bullet)$, liver $(\bullet)$ and white muscle $(\nabla)$ of female yellowfin tuna from the Western Indian Ocean

801 as a function of maturity (i.e., ovarian development phases and stages). The letters show the significant

802 differences between the different stage of oocyte development and the three tissues.

803 Fig. 4 Results of the significant interaction between school type and tissue (gonads, liver and muscle) for

804 yellowfin tuna described by the mixed ANCOVA model for (A) phospholipids (PL), (B) total lipids and

805 (C) acetone mobile polar lipids (AMPL). The letters show the significant differences between females

806 caught at FADs and females caught in free-swimming schools by tissue.

807

808

809

810

811

812

813

814

815

816

817

818 
$820 \quad$ Fig.1

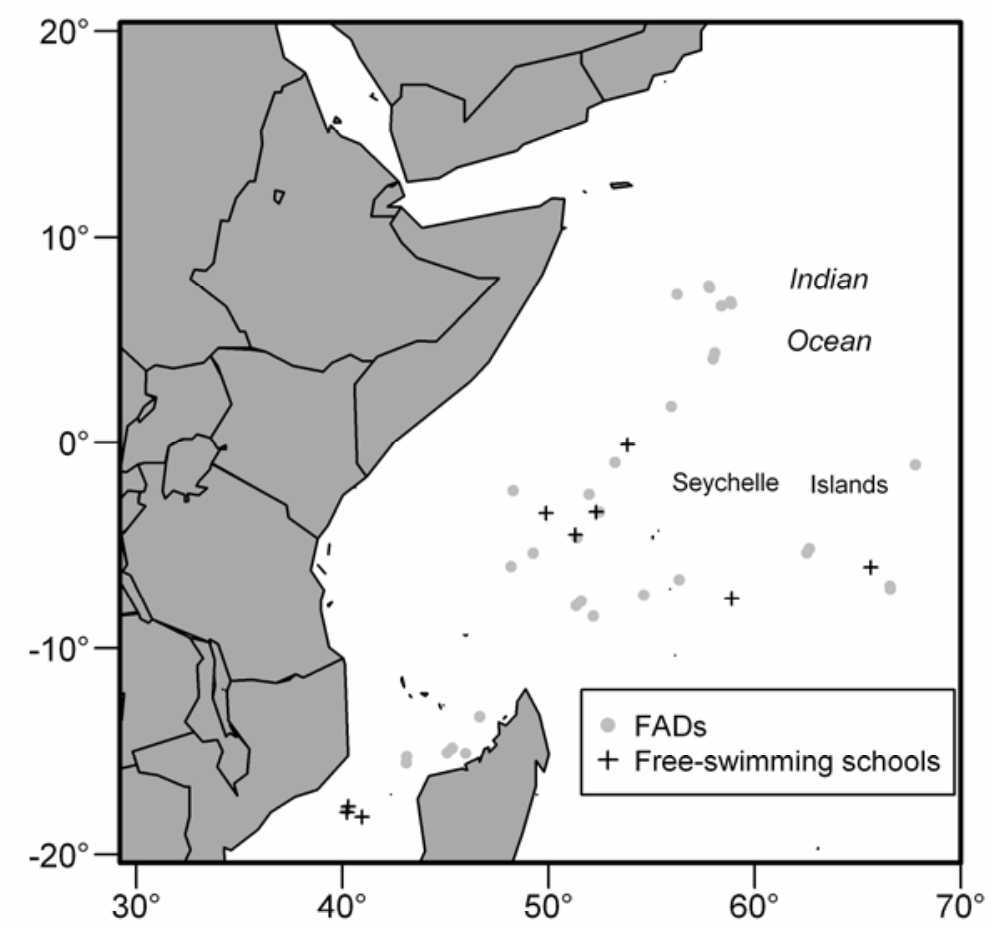

821

822

823

824

825

826

827

828

829

830

831

832

833

834 
$836 \quad$ Fig.2

A
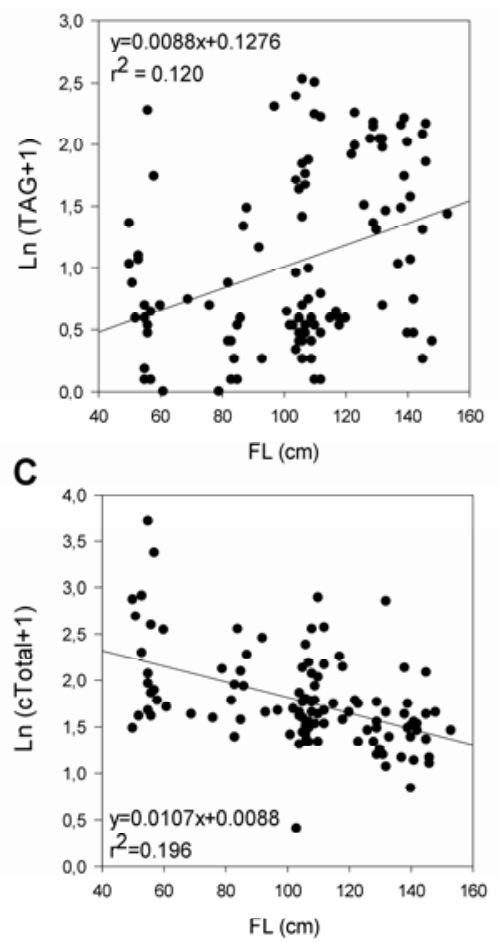

B

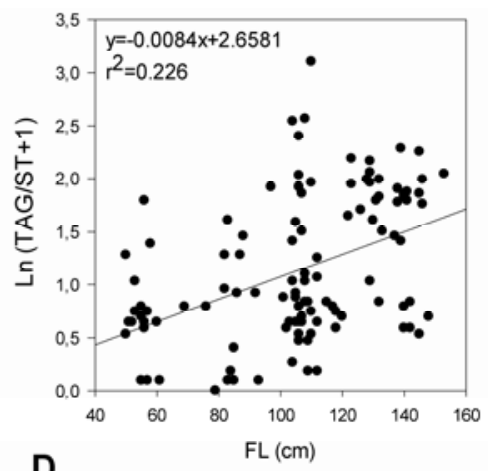

D

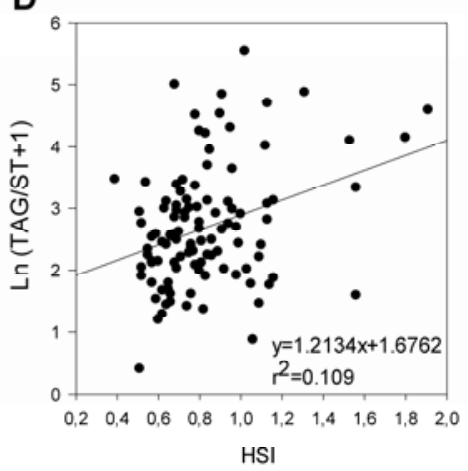

837

838

839

840

841

842

843

844

845

846

847

848

849

850

851 
$853 \quad$ Fig.3

854
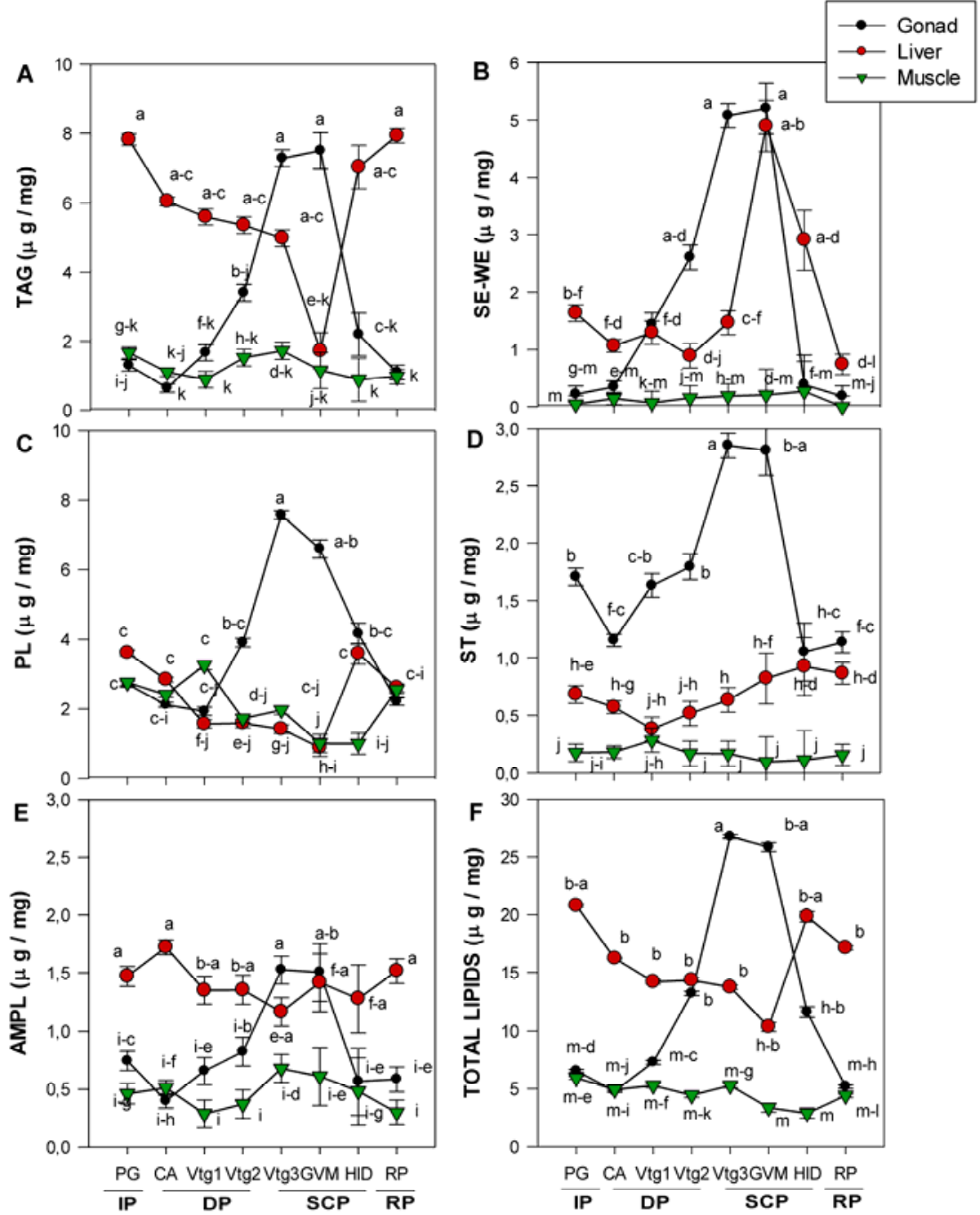

855

856

857

858

859

860

861

862

863

864

865 
866

$867 \quad$ Fig.4

868
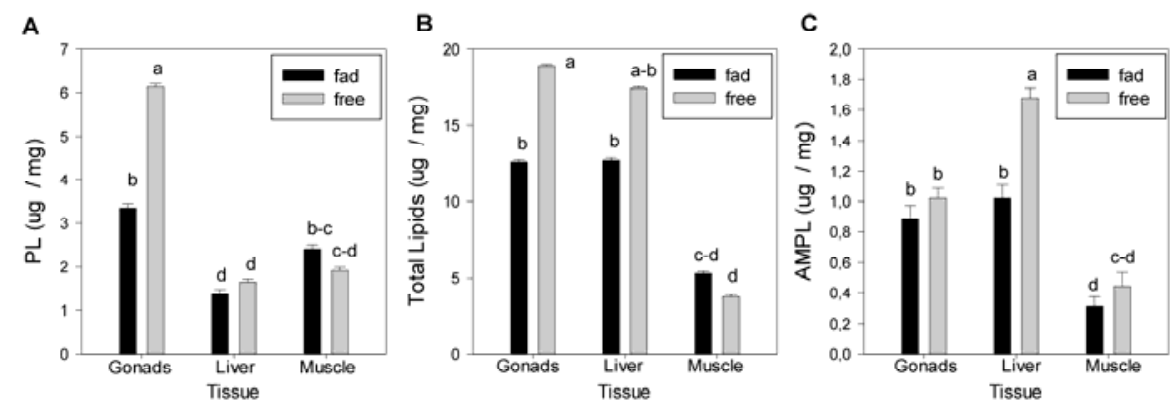